\title{
COMPARISON OF OPERATIONAL AVAILABILITY OF PUBLIC CITY BUSES BY ANALYSIS OF VARIANCE
}

\section{PORÓWNANIE GOTOWOŚCI AUTOBUSÓW KOMUNIKACJI MIEJSKIEJ ZZASTOSOWANIEM METODY ANALIZY WARIANCJ**}

\begin{abstract}
This paper analyses the influence of selected factors of operational availability of public city buses from the Municipal Transport Company (MPK) in Lublin based on a case study for two makes of buses: Solaris and Mercedes-Benz. The study investigated changes in operational availability in a function of operating time with a division into two periods of operation: warranty and post-warranty. To evaluate the significance of differences between average operational availability with regards to the above periods, one-way analysis of variance was applied. The results demonstrate that in the warranty period the operational availability of both makes of buses is similar, while the post-warranty period reveals a significant difference, with the operational availability being higher for Mercedes buses. As a result, this method can be of use for investment projects during purchase of new vehicles.
\end{abstract}

Keywords: public city buses, analysis of variance, ANOVA, operational availability.

\begin{abstract}
Celem pracy była analiza wpływu wybranych czynników gotowości technicznej autobusów komunikacji miejskiej na przykładzie autobusów marki Solaris i Mercedes-Benz w Miejskim Przedsiębiorstwie Komunikacyjnym (MPK) w Lublinie. Przeprowadzono badania zmian gotowości technicznej w funkcji czasu użytkowania z podziałem na dwa okresy użytkowania: gwarancyjny i pogwarancyjny. Do sprawdzenia istotności różnic średnich wartości gotowości technicznej, w zależności od marki autobusów oraz w zależności od okresów eksploatacji zastosowano jednoczynnikowa analize wariancji. Wykazano, że w okresie gwarancyjnym gotowość techniczna autobusów obu marek jest porównywalna, natomiast w okresie pogwarancyjnym jest istotnie różna, wyższa dla autobusu marki Mercedes. W rezultacie metoda ta może zostać użyta do programu inwestycyjnego podczas zakupu nowych pojazdów.
\end{abstract}

Stowa kluczowe: autobusy komunikacji miejskiej, analiza wariancji, ANOVA, gotowość techniczna.

\section{Introduction}

There are numerous works on availability studies, among others. In [3] a general overview of main strategies and technical steps which should be taken when designing an optimum public transportation system. Operational availability as a characteristic of transportation systems is used for analysis of so-called fast reaction systems in random moments of operations $(t)$, for example air force, emergency medical services, fire brigades or public transportation systems [5]. Analysis of availability of different systems has been researched into by many studies in recent years. Nowadays it is applied in many sectors of the industry, including aircraft and defense sectors as well as power engineering and transportation. In [5] the authors present the possibilities of application of the RAM (Reliability, Availability and Maintainability) model in industry to identify unreliable devices with respect to operation-related frequent failures or requirements.

In [23] the authors investigate the dependencies between availability and maintainability of transportation modes and the costs of unplanned breaks and vehicle operation. The authors developed an economically-optimum model of implementation for inspection and technical services that was based on current data on vehicle damage. The study [19] examined several scenarios regarding the reliability of buses and repair service employees' shift system in a transport company to increase the vehicle's availability and reduce costs of the whole system regarding its disturbance at vehicle failure. In [18] and [28] the authors present an optimization model of public transportation considering the design of transit routes, selection of modes of transportation and timetables. The study [24] presents a method of designing the availability of technological objects, and in [10] a theory pertaining to semi-Markov processes was used based on the authentic municipal transport system. In [2] the authors identified the object's aptitude condition, and thus optimal control processes of operation and service of particular objects on the example of public transportation bus engines.

In [27] the authors present different methods applied to estimate a functional form between overall quality of service and explanatory variables, including questionnaire items related to satisfaction accessibility (availability, information, time characteristics of service, customer service, comfort, safety, infrastructure and environment).

The operational availability index was mainly used for bus schedule reliability and current monitoring of transportation systems, especially vehicle punctuality $[3,4,26]$ however, it was not often used to control quality management systems and maintenance of a given make of a vehicle.

The municipal transport company should assure a continuous monitoring on maintenance process in terms of current availability of used fleet. Resting on this assumption, the authors of the paper conducted studies on operational availability of buses of the selected makes from

$\left(^{*}\right)$ Tekst artykułu w polskiej wersji językowej dostępny w elektronicznym wydaniu kwartalnika na stronie www.ein.org.pl 
the Municipal Transport Company (MPK) in Lublin during 6 years of their operation. This paper includes the findings of previous studies presented in [16] and [17] which are related to operational availability and reliability of buses. Also, the paper [12] presented some aspects of operation of the municipal transport system in the city of Lublin. In the present paper, the study period of the sample is extended and analysis by the one-way ANOVA method is conducted.

\section{Theoretical aspects of operational availability of public buses and ANOVA analysis}

The availability of a technical object is defined as the probability of an object's usability [13]. It is interpreted as the probability of an object's ability to undertake work in a defined time $[9,20]$. When a system is in standby, this means that the system is neither out of operation due to preventive maintenance service nor useless due to failure. Thus, the object's availability depends not only on maintenance-related breaks, but also on the probability of the system's not performing its assigned functions (failure effect) [21]. The aim of effective maintenance is to reduce the time of unplanned system breaks (Mean Down Time MDT) and related costs [29]. Based on the literature $[3,13,20,24,25]$ and data collected from MPK in Lublin, it has been assumed that the operational availability will be defined in this study according to the following formula:

$$
K_{g}(t)=\frac{N_{z}-N_{n}}{N_{z}} \times 100
$$

where:

$\mathrm{N}_{\mathrm{z}}$ - is the number of technical objects available for use in a given operating period in a given transport system;

$\mathrm{N}_{\mathrm{n}}$ - is the number of technical objects unavailable for use in a given operating period in a given transport system.

The aim of evaluating operational availability of buses is usually to predict if a given technical object will be available in the future and if a transport task can be executed.

This paper applies the analysis of variance to availability of a technical system. The analysis of variance (ANOVA) was formulated by Fisher in the 1920s [11, 22]. The method allows us to evaluate the influence of independent classifying factor $x_{j}(\mathrm{j}=1, \ldots, \mathrm{m})$ on distribution of the dependent variable $y$. The analysis enables verifying if average values of the variable y for many samples are comparable. The analysis of variance was used by many authors such as $[1,7,15]$ usually as a complementary analysis.

Based on the results of calculations, a zero hypothesis has to be verified with respect to equality of average values of the dependent variable for all $k$ levels of the classifying factor:

$$
\mathrm{H}_{0}: \bar{y}_{1}=\bar{y}_{2}=\ldots=\bar{y}_{k}
$$

where:

$\bar{y}_{i}(i=1, \ldots k)$, refers to an average value of the discussed variable for the k-th level of factor.

An alternative hypothesis $H_{l}$ is that at least two from the averages $\mathrm{y}_{1}, \ldots \mathrm{y}_{\mathrm{k}}$ are different, thus:

$$
\bar{y}_{i}(i=1, \ldots k)
$$

The one-factor ANOVA is used to check the statistical significance between independent groups based on differences in variance between the groups or within them. In the paper, the analysis of vari- ance between groups MS Effect was applied according to the following sum of square equations [25]:

$$
\begin{gathered}
S S_{\text {all }}=\sum_{i=1}^{p} \sum_{j=1}^{n}\left(y_{i j}-\bar{y}\right)^{2} \\
S S_{\text {between }}=n \sum_{i=1}^{p}\left(\bar{y}_{i}-\bar{y}\right)^{2} \\
S S_{\text {within }}=\sum_{i=1}^{p} \sum_{j=1}^{n}\left(y_{i j}-\bar{y}_{i}\right)^{2}
\end{gathered}
$$

The degree of freedom DF between the groups is equal to the number of groups reduced by one. Inside the groups it is equal to the number of observations minus the number of groups. The MS variance is equal to the quotient of the sum of squares of freedom degrees. At the same time, the variance test is based on designation of the statistics $\mathrm{F}=\mathrm{SS}_{\text {between }} / \mathrm{SS}_{\text {within }}$. The higher the $\mathrm{F}$ statistic is, the greater influence it has.

Assumptions that are fundamental for the analysis of variance include:

- measurability of dependent variables on a quantitative scale;

- independence of random variables in the analysed groups;

- normality of distribution of the dependent variable for each factor;

- homogeneity of variance for each factor.

In order to verify the thesis about normal distribution of the dependent variable, one of the following statistic tests can be used: $\chi 2$, Shapiro-Wilk's, Lilliefor's or a similar one using the quantile curve [8]. In order to verify the thesis about homogeneity of variance, the following tests can be applied: Levene's, Barlett's, Cochran's. Levene's test is the most resistant to deviations from normal probability distribution of the results, however Barlett's test works better when the criterion of normal distribution of the results is met.

\section{Details of the study}

The study was performed on 22 Mercedes-Benz 628 Conecto LF buses and 20 Solaris Urbino 12 buses. All buses were observed from the first day of their operation. The initial maintenance mileage was low and comparable for both makes of vehicles. The studies were conducted under natural conditions over 6 years of operation (20082014). The operational availability of the buses was recorded over calendar time from the first to the seventy-second month of operation. This corresponded to a total maintenance mileage equal to 7.73 million $\mathrm{km}$ for all 20 Solaris buses and 7.29 million $\mathrm{km}$ for all 22 Mercedes buses, respectively. An average monthly mileage from the last 72 months of operation was $6096 \mathrm{~km}$ for Solaris buses and 6464 $\mathrm{km}$ for Mercedes buses.

\section{Empirical results}

The operational availability factor of Solaris and Mercedes-Benz buses with regards to calendar time as a function of monthly operating time is presented in Figure 1. In the first period of operation (warranty), thus up till approx. the twentieth month of operation, the availability of Solaris buses was 0.897 on average. Afterwards, the factor started to decrease, reaching in the sixty-second month of operation the lowest value -0.700 . An average operational availability for the whole study period was 0.870 for Solaris buses and 0.908 for Mercedes buses, respectively. The average availability of Mercedes buses was higher only by $3.8 \%$ and was equal to 0.909 at a standard deviation of 0.059 . The paper [6] analyzes the factors related to maintenance costs of buses, including the costs of fluids, repair and maintenance services. 


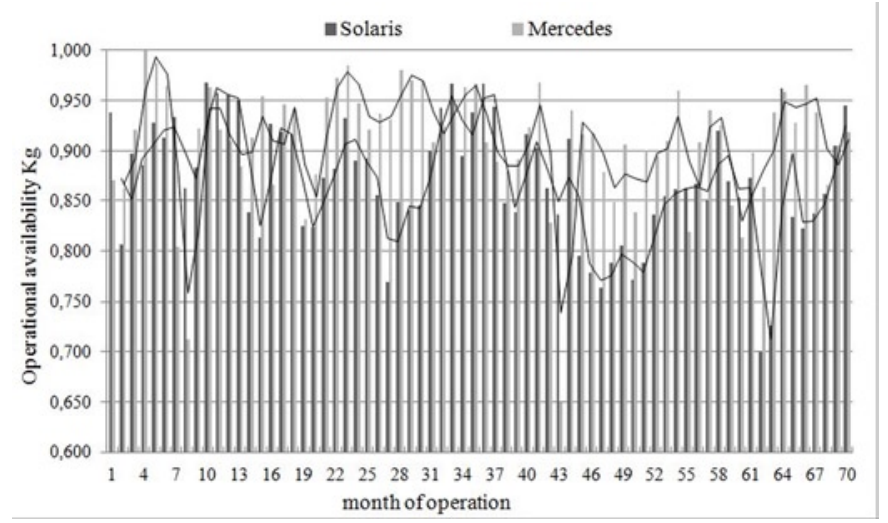

Fig. 1. Operational availability Kg of buses versus operating time (months)

- Median $\square 25 \%-75 \%$ I non-deviating range

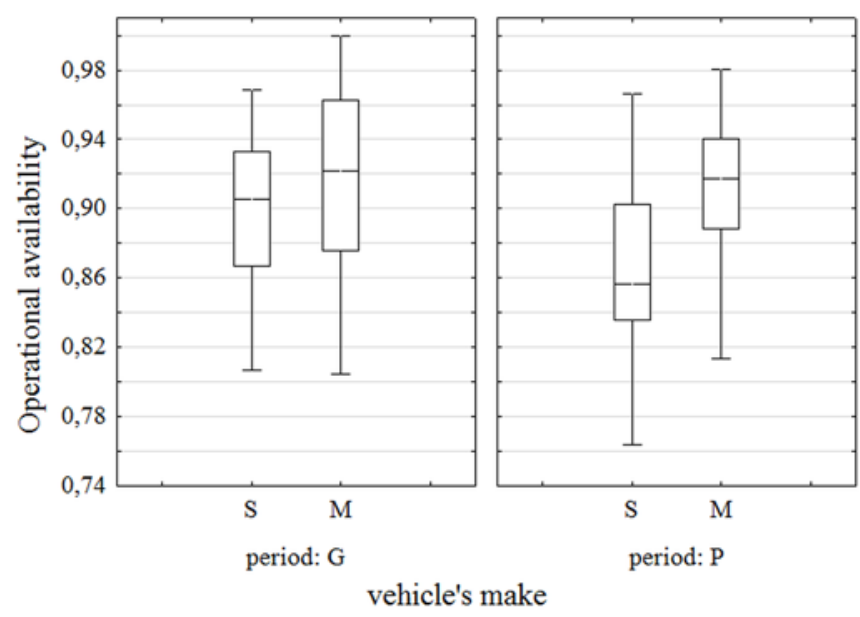

Fig. 2. Box plot of dependent variable - availability of uses (S-Solaris, MMercedes) in warranty $(G)$ and post-warranty $(P)$ periods

Categorized normal probability plots

vehicle's make: $\mathrm{S}$, period: $\mathrm{G}$ technical availability: $\mathrm{SW}-\mathrm{W}=0,9406 ; \mathrm{p}=0,1680$ vehicle's make: $\mathrm{S}$, period: $\mathrm{P}$ technical availability: $\mathrm{SW}-\mathrm{W}=0,9637 ; \mathrm{p}=0,1601$ vehicle's make: $\mathrm{M}$, period: $\mathrm{G}$ technical availability: $\mathrm{SW}-\mathrm{W}=0,9589 ; \mathrm{p}=0,4414$ vehicle's make: M, period: $\mathrm{P}$ technical availability: $\mathrm{SW}-\mathrm{W}=0,9584 ; \mathrm{p}=0,0925$

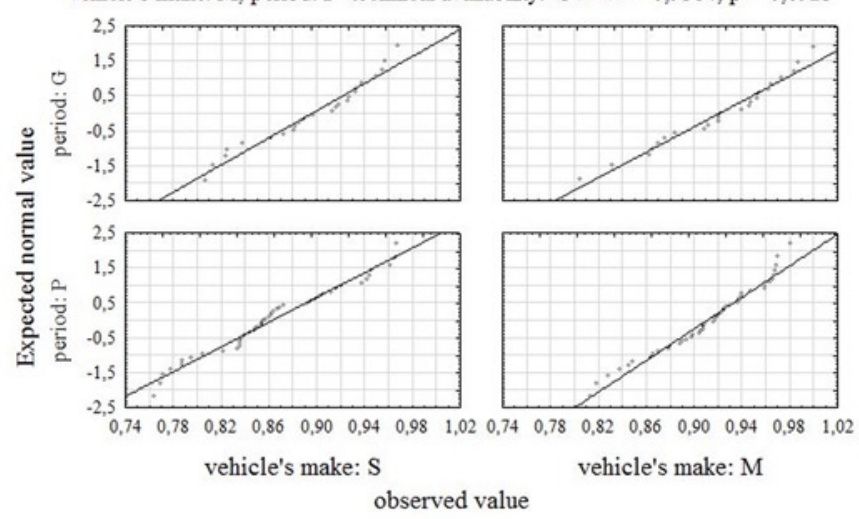

Fig. 3. Categorized normal probability plots in warranty $(G)$ and post-warranty $(P)$ periods

The outliers in specific periods of vehicle use were verified and excluded from further calculations. The results of operational availability divided into two groups: warranty (1-24 months) and post-warranty (25-72 months), are presented in Figure 2. In order to verify the significance of differences in average operational availability of both makes of buses, a one-way analysis of variance was conducted.
Table 1. Results of Levene's test for warranty and post-warranty periods

\begin{tabular}{|c|c|c|c|c|c|c|}
\hline \multirow[t]{2}{*}{$\begin{array}{l}\text { Operating } \\
\text { period }\end{array}$} & \multirow[t]{2}{*}{ Variable } & \multirow[t]{2}{*}{ Effect } & \multicolumn{4}{|c|}{$\begin{array}{l}\text { Levene's test of variance homogeneity } \\
\text { Marked effects are significant } \\
\text { with } p<0.05000\end{array}$} \\
\hline & & & MS Effect & MS Error & $\mathrm{F}$ & $p$ \\
\hline warranty & opera- & & 0.00003 & 0.00077 & 0.04228 & 0.83801 \\
\hline $\begin{array}{c}\text { post- } \\
\text { warranty }\end{array}$ & $\begin{array}{l}\text { availabi- } \\
\text { lity }\end{array}$ & $\begin{array}{l}\text { cle's } \\
\text { make }\end{array}$ & 0.00188 & 0.00088 & 2.12498 & 0.14836 \\
\hline
\end{tabular}

Table 2. Results of Hartley, Bartlett and Cochran tests for warranty and postwarranty periods

\begin{tabular}{|c|c|c|c|c|c|c|c|}
\hline \hline \multirow{2}{*}{$\begin{array}{c}\text { Operat- } \\
\text { ing pe- } \\
\text { riod }\end{array}$} & \multirow{2}{*}{ Variable } & & \multicolumn{5}{|c|}{ Effect of variance homogeneity } \\
\cline { 4 - 8 } & & $\begin{array}{c}\text { Hart- } \\
\text { ley }\end{array}$ & $\begin{array}{c}\text { Co- } \\
\text { chran }\end{array}$ & Bartlett & DF & $\mathrm{p}$ \\
\hline warranty & $\begin{array}{c}\text { opera- } \\
\text { tional }\end{array}$ & $\begin{array}{c}\text { vehi- } \\
\text { cle's } \\
\text { post- } \\
\text { availa- } \\
\text { warranty }\end{array}$ & 1.1540 & 0.5357 & 0.1129 & 1 & 0.7369 \\
\hline make & 1.6325 & 0.6201 & 2.6802 & 1 & 0.1016 \\
\hline
\end{tabular}

The analysed variables are measurable and independent, therefore, the two first assumptions of variance analysis are met. Factors such as a make of a bus and warranty and post-warranty periods are independent. The $\mathrm{Kg}$ factor is measurable. The normal probability of distribution (third fundamental assumption) in the studied groups of data was evaluated, creating categorized normal probability plots for each group (a make of a bus). Given that according to ShapiroWilk's test the significance level in all four cases is higher, $p>\alpha=0.05$, there are no grounds for rejecting the zero hypothesis $(\mathrm{H} 0)$ on the normal probability of distribution of operational availability of vehicles (Fig. 3).

Next, the fourth assumption on variance homogeneity was verified. Tables 1 and 2 show the probability results with respect to effect (a make of a bus) and type of operating period: warranty and postwarranty. Analyzing the obtained data by means of two normal probability tests, there are no grounds for rejection of the zero hypothesis in both operating periods of the analysed vehicles. Therefore, it can be concluded that the assumption on homogeneity of variance is met in all four cases.

The one-way variance analysis was conducted to examine the influence of a make of a bus on the vehicle's operational availability in two operating periods: warranty and post-warranty. It can be concluded from Table 3 that the significance level $\mathrm{p}$ for the vehicle's make in the warranty period is higher than 0.05 , thus $\mathrm{p}=0.0929$, therefore there

Table 3. Results of one-way analysis of variance in warranty and post-warranty operating periods

\begin{tabular}{|c|c|c|c|c|c|c|}
\hline \multirow{2}{*}{$\begin{array}{l}\text { Operating } \\
\text { period }\end{array}$} & \multirow[t]{2}{*}{ Effect } & \multicolumn{5}{|c|}{$\begin{array}{l}\text { Univariate significance tests for the dependent } \\
\text { variable: technical availability }\end{array}$} \\
\hline & & SS & DF & MS & $\mathrm{F}$ & $p$ \\
\hline \multirow{3}{*}{ warranty } & $\begin{array}{l}\text { free } \\
\text { term }\end{array}$ & 38.805 & 1 & 38.805 & 15498.3 & 0.0000 \\
\hline & $\begin{array}{l}\text { vehicle's } \\
\text { make }\end{array}$ & 0.007 & 1 & 0.007 & 2.95 & 0.0929 \\
\hline & error & 0.113 & 45 & 0.0025 & - & - \\
\hline \multirow{3}{*}{$\begin{array}{c}\text { post- } \\
\text { warranty }\end{array}$} & $\begin{array}{l}\text { free } \\
\text { term }\end{array}$ & 73.22 & 1 & 73.22 & 30934 & 0.0000 \\
\hline & $\begin{array}{l}\text { vehicle's } \\
\text { make }\end{array}$ & 0.053 & 1 & 0.053 & 22.58 & 0.0000 \\
\hline & error & 0.215 & 91 & 0.002 & - & - \\
\hline
\end{tabular}


Vehicle's make; warranty operating period Current effect: $F(1,45)=2,9475, p=0,09289$

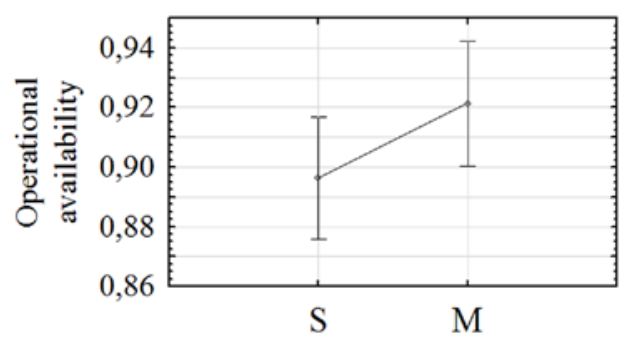

vehicle's make

Fig. 4. Operational availability interaction curve in the operating warranty periods for Mercedes (M) and Solaris (S) buses

Vehicle's make; post-warranty operating period Current effect: $F(1,91)=22,580, p=0,00001$

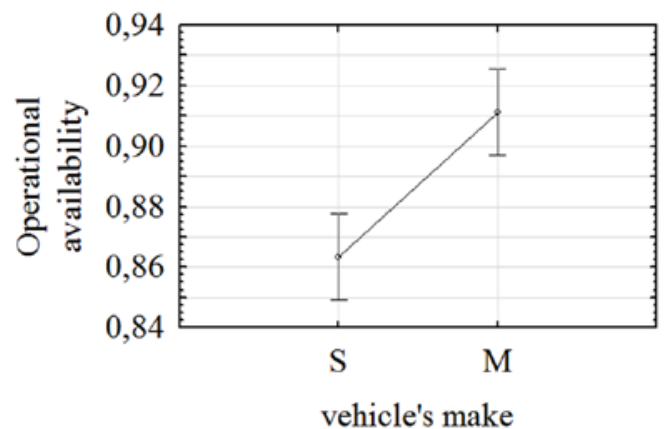

Fig. 5. Operational availability interaction curve in the operating post-warranty periods for Mercedes (M) and Solaris (S) buses

Operating period for Solaris buses; Current effect: $\mathrm{F}(1,68)=6,2560, \mathrm{p}=0,01479$

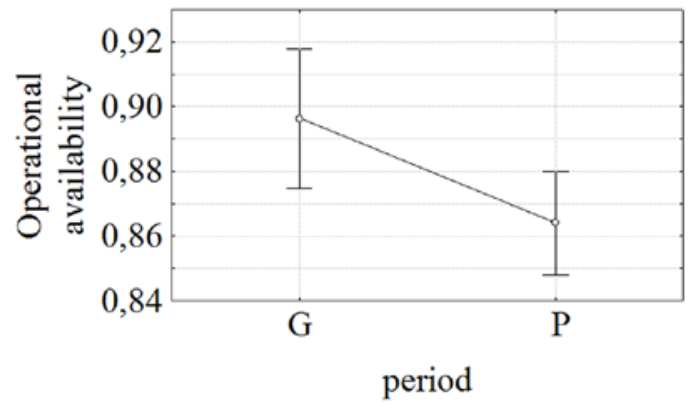

Fig. 6. Operational availability interaction curve for "operating periods": Solaris buses in warranty and post-warranty periods

Operating period for Mercedes buses; Current effect: $\mathrm{F}(1,68)=0,74797, \mathrm{p}=0,39016$

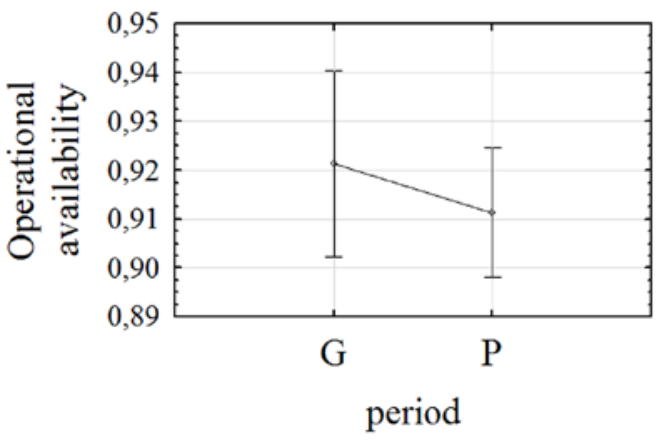

Fig. 7. Operational availability interaction curve for "operating periods". Mercedes buses in warranty and post-warranty periods

The test results of variance analysis are confirmed by interaction curve (Figs. 4 and 5). The curve illustrates the confidence intervals of $95 \%$ and average availability for the analysed operating periods. The average availability of Mercedes buses in the warranty and post-warranty periods is higher than that of Solaris buses, and a relative difference is $2.5 \%$ and $4.8 \%$ for the given operating period.

The following stage of variance analysis was conducted for the investigated operating periods, i.e. warranty and post-warranty. The normal probability test results were confirmed as per Fig. 3. Tables 4 and 5 list the probability values of tests of homogeneity assumptions of variance for classifying the effect of "operating period". Analyzing the obtained results by means of two normal probability tests, there are no grounds for rejection of the zero hypothesis that

are no grounds for rejection of the zero hypothesis (H0). This indicates that the average operational availability in the warranty period for buses of both analysed makes does not differ significantly. The probability that $\mathrm{F}=22.58$ in the post-warranty period equals $\mathrm{p}=0.0000$. It means that with the test statistics assumed to be $\mathrm{p}=0.05$, the zero hypothesis (H0) should be rejected and an alternative hypothesis (H1) should be adopted on statistically significant difference of averages in individual groups in the post-warranty period. It can therefore be concluded that for the post-warranty period the value of operational availability differs significantly for both analysed makes of buses. $p>0.05$. The assumption of homogeneity of variance is therefore met in all four cases.

A one-way analysis of variance was conducted to investigate the influence of "operating period" on operational availability of Solaris and Mercedes buses. It can be concluded from Table 6 that the significance level $\mathrm{p}$ for Solaris buses is lower than expected, as it equals $\mathrm{p}=0.0148$, therefore the zero hypothesis on equal averages should be rejected. This demonstrates a significant difference in operational availability of Solaris buses in the warranty and post-warranty periods. 
Table 6. Results of one-way analysis of variance for "operating period"

\begin{tabular}{|c|c|c|c|c|c|c|}
\hline \multirow{2}{*}{$\begin{array}{c}\text { Operating } \\
\text { period }\end{array}$} & \multicolumn{4}{|c|}{ Enivariate significance tests for the dependent variable: } \\
operational availability
\end{tabular}

For Mercedes buses $p$ is higher than expected, $p=0.3902$, therefore there are no grounds for rejecting the zero hypothesis. The average operational availability of Mercedes in the warranty and post-warranty periods does not differ significantly. The test results of variance analysis are also confirmed by the interaction curve (Figs. 6 and 7).

\section{Conclusions}

Based on the conducted studies, the following conclusions have been formulated:

\section{References}

1. Caro, E., Arévalob, I., García-Martosa, C., Conejoc, A.J.: Power system observability via optimization. Electric Power Systems Research 2013; 104, 207-215, http://dx.doi.org/10.1016/j.epsr.2013.06.019.

2. Grądzki, R., Lindstedt, P.: Method of assessment of technical object aptitude in environment of exploitation and service conditions. Eksploatacja i Niezawodnosc - Maintenance and Reliability 2015; 17(1): 54-63, http://dx.doi.org/10.17531/ein.2015.1.8.

3. Guihaire, V., Hao, J.K.H.: Transit network design and scheduling: A global review. Transportation Research Part A. 2008; 42: 1251-1273, http://dx.doi.org/10.1016/j.tra.2008.03.011.

4. Guihaire, V., Hao, J.K.H.: Transit network timetabling and vehicle assignment for regulating authorities. Computers \& Industrial Engineering 2010; 59: 16-23, http://dx.doi.org/10.1016/j.cie.2010.02.005.

5. Herder, P.M., van Luijk, J.A., Bruijnooge, J.: Industrial application of RAM modeling development and implementation of a RAM simulation model for the Lexan plant at GE Industrial. Reliability Engineering \& System Safety 2008; 93: 501-508, http://dx.doi.org/10.1016/j. ress.2006.10.019.

6. Ignaciuk, P., Rymarz, J., Niewczas, A.: Effectiveness of the failure rate on maintenance costs of the city buses. Journal of KONBiN 2015; 3(35): 99-108.

7. Kadiyala, A., Kumar, A.: Development and application of a methodology to identify and rank the important factors affecting in-vehicle particulate matter. Journal of Hazardous Materials 2013; 213-214: 140-146, http://dx.doi.org/10.1016/j.jhazmat.2012.01.072.

8. Koronacki, J., Mielniczuk, J. Statystyka dla studentów kierunków technicznych i przyrodniczych. Warszawa: Wydawnictwa Naukowo Techniczne, 2001.

9. Legutko, S. Podstawy eksploatacji maszyn i urządzeń. Warszawa: Wydawnictwo Szkolne i Pedagogiczne, 2004.

10. Migawa, K.: Semi-Markov model of the availability of the means of municipal transport system. Scientific Problems of Machines Operation and Maintenance 2009; 3(159): 25-34.

11. Misra, K.B. Red. Handbook of Reliability Engineering. London: Springer Verlag, 2008.

12. Niewczas, A., Koszałka, G., Wrona, J., Pieniak, D.: Chosen aspects of municipal transport operation on the example of the city of Lublin. Transport 2008; 23(1): 88-90, http://dx.doi.org/10.3846/1648-4142.2008.23.88-90.

13. Pham, H. Handbook of Reliability Engineering. London: Springer Verlag, 2003, http://dx.doi.org/10.1007/b97414.

14. Piasecki, S. Zagadnienia użytkowania maszyn i środków transportowych. Lublin: Lubelskie Towarzystwo Naukowe, 1995.

15. Portela, S.B., Queiroga, R.M., Constantini, A., Zannin, H.T.P.: Annoyance evaluation and the effect of noise on the health of bus drivers. Noise Health 2013; 15(66): 301-306, http://dx.doi.org/10.4103/1463-1741.116561.

16. Rymarz, J., Niewczas, A., Pieniak, D.: Reliability analysis of the selected brands of city buses at municipal transport company. J. Konbin 2013; 26(1): 111-122, http://dx.doi.org/10.2478/jok-2013-0087.

17. Rymarz, J., Niewczas, A.: Ocena gotowości technicznej autobusów komunikacji miejskiej na przykładzie Miejskiego Przedsiębiorstwa Komunikacyjnego w Lublinie. Czasopismo Techniczne 2013; 9(109): 195-200.

18. Sanchez, S.A.: Optimizing performance-based mechanisms in road management: An agency theory approach. European Journal of Transport and Infrastructure Research 2015; 15(4): 465-481.

19. Savsar, M.: Modeling and simulation of maintenance operations at Kuwait public transport company. Kuwait Journal of Science 2013; 40(2): $115-129$. 
20. Stapelberg, R.F. Red. Handbook of reliability, availability, maintainability and safety in engineering design. London: Springer Verlag, 2009.

21. Szkoda, M.: Assessment of Reliability, Availability and Maintainability of Rail Gauge Change Systems. Eksploatacja i Niezawodnosc Maintenance and Reliability 2014; 16(3): 422-432.

22. Walesiak, M., Gatnar, E. Statystyczna analiza danych z wykorzystaniem programu R. Warszawa: Wydawnictwo Naukowe PWN, 2009.

23. Wolde, M., Ghobbar, A.A.: Optimizing inspection intervals - Reliability and availability in terms of a cost model: A case study on railway carriers. Reliability Engineering \& System Safety 2013; 114: 137-147, http://dx.doi.org/10.1016/j.ress.2012.12.013.

24. Woropay, M., Szubartowski, M., Migawa, K. Model oceny i kształtowania gotowości operacyjnej podsystemu wykonawczego w systemie transportowym. Radom: Wydawnictwo i Zakład Poligrafii Instytutu Technologii Eksploatacji, 2013.

25. Woropay, M., Żurek, J., Migawa, K. Model oceny i kształtowania gotowości operacyjnej podsystemu utrzymania ruchu w systemie transportowym. Radom: Wydawnictwo i Zakład Poligrafii Instytutu Technologii Eksploatacji, 2003.

26. Xuan, Y., Argote, J., Daganzo, C. F.: Dynamic bus holding strategies for schedule reliability: Optimal linear control and performance analysis. Transport Research Part B 2011; 45: 1831-1845, http://dx.doi.org/10.1016/j.trb.2011.07.009.

27. Yatskiv, I., Pticina, I., Savrasovs, M.: Urban public transport system's reliability estimation using microscopic simulation. Transport Telecommununication 2012; 13(3): 219-228, http://dx.doi.org/10.2478/v10244-012-0018-4.

28. Zhao, F., Zeng, X.: Optimization of transit route network, vehicle headways and timetables for large-scale transit networks. European Journal of Operational Research 2008; 186: 841-855, http://dx.doi.org/10.1016/j.ejor.2007.02.005.

29. Zio, E.: Reliability engineering: Old problems and new challenges. Reliability Engineering and System Safety 2009; 94(2): 125-141, http:// dx.doi.org/10.1016/j.ress.2008.06.002.

Joanna RYMARZ

Lublin University of Technology

ul. Nadbystrzycka 36, 20-816 Lublin, Poland

\section{Andrzej NIEWCZAS}

Motor Transport Institute

ul. Jagiellońska 80, 03-301 Warsaw, Poland

\section{Aneta KRZYŻAK}

Polish Air Force Academy

ul. Dywizjonu 303 35, 08-521 Dęblin, Poland

E-mails: j.rymarz@pollub.pl, andrzej.niewczas@its.waw.pl, a.krzyzak@wsosp.pl 